Teologia i Moralność, volumen 12(2017), numer 2(22)

doi: $10.14746 /$ tim.2017.22.2.12

MIKOŁAJ GĘBKA

Uniwersytet im. Adama Mickiewicza w Poznaniu

Wydział Teologiczny

\title{
Polityka rodzinna Polski a Evangelium vitae
}

Ponad dwie dekady temu ukazała się poświęcona problematyce ochrony życia encyklika Jana Pawła II Evangelium vitae ${ }^{1}$. Została ona ogłoszona zaledwie kilka miesięcy po kairskiej Międzynarodowej Konferencji ONZ nt. Zaludnienia i Rozwoju, której jednym z tematów przewodnich była kwestia aborcji. Dominującym wątkiem wspomnianej encykliki jest ochrona życia ludzkiego oraz jego godności, zarówno u początku ludzkiej egzystencji (zagrożenie przede wszystkim aborcją, ale również wymienianą w tym kontekście procedurą in vitro), jak i u jego kresu (kwestia eutanazji). W tekście można jednak znaleźć również refleksje dotyczące przemian demograficznych i problemów z nimi związanych (np. spadku liczby urodzeń w państwach bogatych czy wysokiego wskaźnika przyrostu ludności w państwach ubogich, skutkującego spowolnieniem rozwoju gospodarczo-społecznego $)^{2}$.

Zarówno w kontekście aborcji, jak i przemian demograficznych, Jan Paweł II wskazuje na duże znaczenie polityki społecznej, a zwłaszcza polityki rodzinnej. Jeśli chodzi o kwestię aborcji, to do grona odpowiedzialnych za decyzję o zabójstwie dziecka zalicza on - oprócz m.in. matki, ojca czy pracowników służby zdrowia - również osoby, które zaniechały odpowiedniej troski „o skuteczną politykę rodzinną i społeczną, wspomagającą rodziny, zwłaszcza wielodzietne albo zmagające się ze szczególnymi trudnościami materialnymi i wychowawczymi"3. Papież podkreśla istotę polityki rodzinnej, która powinna być „filarem i motorem wszelkiej polityki społecznej”, zaznacza-

\footnotetext{
${ }^{1}$ Por. Jan Paweł II, Evangelium vitae, w: Posoborowe dokumenty Kościoła Katolickiego o matżeństwie i rodzinie, red. K. Lubowiecki, t. II, Kraków $1999^{2}$.

${ }^{2}$ Por. tamże (punkt 16).

${ }^{3}$ Tamże, s. 221 (punkt 59).

${ }^{4}$ Tamże, s. 260 (punkt 90).
} 
jąc również, że dla przywrócenia właściwego ładu nie wystarczy zniesienie uregulowań prawnych dopuszczających aborcję, ale konieczne jest usunięcie przyczyn jej sprzyjających - zwłaszcza przez zapewnienie stosownej pomocy macierzyństwu i rodzinie. Chodzi zatem o stworzenie warunków pozwalających na podejmowanie decyzji prokreacyjnych w ,autentycznej wolności”5.

Z kolei jeśli chodzi o przemiany demograficzne, to Jan Paweł II wskazuje na brak odpowiednich działań ze strony społeczności międzynarodowej w kontekście przeludnienia w państwach ubogich - tutaj zamiast „,poważnej polityki rodzinnej i społecznej oraz programów zmierzających do postępu kulturowego i do sprawiedliwego podziału dóbr" ${ }^{\prime}$ dominują różne formy działań antynatalistycznych. Papież zwraca uwagę, że państwa mają wprawdzie prawo do ukierunkowywania demografii, niemniej w swych działaniach muszą respektować „pierwotną niezbywalną odpowiedzialność małżonków i rodzin”, jeśli chodzi o sferę prokreacji. Nie powinny także „uciekać się do metod sprzecznych z godnością osoby"8 (antykoncepcja, sterylizacja, aborcja), powinny natomiast dążyć do „stworzenia warunków ekonomicznych, społecznych, medycznych, sanitarnych i kulturowych, które pozwolą małżonkom podejmować decyzje o prokreacji z pełną wolnością i z prawdziwą odpowiedzialnością"

W kontekście przywołanych myśli warto zastanowić się, pozostawiając na marginesie kwestię aborcji, czy polityka rodzinna realizowana w Polsce przyczynia się do otwarcia na nowe życie, sprzyjając świadomym i odpowiedzialnym decyzjom prokreacyjnym?

\section{Rozrodczość w powojennej Polsce}

Polska w swej powojennej historii przeżyła dwa okresy wzmożonej rozrodczości - pierwszy przypadł na lata 50. XX wieku (liczba urodzeń żywych sięgnęła w roku 1955793,8 tys.), drugi - na przełom lat 70. i 80. (liczba urodzeń sięgająca w roku 1983 723,6 tys.), jednakże od połowy lat 80. można było zaobserwować systematyczny spadek liczby urodzeń żywych, który trwał do roku 2003, kiedy odnotowana została najniższa w powojennej historii Polski liczba żywych urodzeń - 351,1 tys. Pod koniec pierwszej dekady XXI wieku odnotowano nieznaczny wzrost, związany wyraźnie $\mathrm{z}$ wejściem w okres decyzji prokreacyjnych przedstawicieli wyżu demograficznego z przełomu

\footnotetext{
${ }^{5}$ Tamże, s. 260 (punkt 90).

${ }^{6}$ Tamże, s. 168 (punkt 16).

${ }^{7}$ Tamże, s. 260 (punkt 91).

${ }^{8}$ Tamże, s. 260 (punkt 91).

${ }^{9}$ Tamże, s. 260 (punkt 91).
} 
lat 70. i 80.: 417,6 tys. urodzeń żywych w roku 2009, w latach 2008 i 2010 przekroczony pułap 400 tys. urodzeń ${ }^{10}$ (na marginesie warto zauważyć, że w latach 2003-2010 odsetek dzieci urodzonych jako pierwsze dziecko matki przekraczał połowę wszystkich urodzeń żywych w danym roku $\left.{ }^{11}\right)$. W latach 2009-2015 następował kolejny spadek liczby urodzeń (za wyjątkiem roku 2014 , kiedy to liczba urodzeń żywych nieznacznie wzrosła ${ }^{12}$, natomiast rok 2016 przyniósł wyraźny wzrost liczby urodzeń.

Tabela 1.

Liczba żywych urodzeń i Total Fertility Rate (dalej: TFR) w latach 1990-2016 ${ }^{13}$

\begin{tabular}{|c|c|c|c|c|c|c|c|c|}
\hline Rok & TFR & $\begin{array}{c}\text { Liczba urodzeń } \\
\text { żywych w tys. }\end{array}$ & Rok & TFR & $\begin{array}{c}\text { Liczba urodzeń } \\
\text { żywych w tys. }\end{array}$ & Rok & TFR & $\begin{array}{c}\text { Liczba urodzeń } \\
\text { żywych w tys. }\end{array}$ \\
\hline 2016 & b. d. & 382,3 & 2007 & 1,306 & 387873 & 1998 & 1,407 & 395619 \\
\hline 2015 & 1,289 & 369308 & 2006 & 1,267 & 374244 & 1997 & 1,468 & 412635 \\
\hline 2014 & 1,290 & 375160 & 2005 & 1,243 & 364383 & 1996 & 1,525 & 428203 \\
\hline 2013 & 1,256 & 369576 & 2004 & 1,227 & 356131 & 1995 & 1,545 & 433109 \\
\hline 2012 & 1,299 & 386257 & 2003 & 1,222 & 351072 & 1994 & 1,720 & 481285 \\
\hline 2011 & 1,297 & 388416 & 2002 & 1,249 & 353765 & 1993 & 1,767 & 494310 \\
\hline 2010 & 1,376 & 413300 & 2001 & 1,315 & 368205 & 1992 & 1,849 & 515214 \\
\hline 2009 & 1,398 & 417589 & 2000 & 1,367 & 378348 & 1991 & 1,976 & 547719 \\
\hline 2008 & 1,390 & 414499 & 1999 & 1,373 & 382002 & 1990 & 1,989 & 547720 \\
\hline
\end{tabular}

O niekorzystnej sytuacji w zakresie rozrodczości w ostatnich latach wiele mówi nie tylko liczba urodzeń - inne wskaźniki demograficzne również ją potwierdzają. Można tu zwrócić uwagę chociażby na współczynnik dzietności

${ }^{10}$ Por. np. Ludność, ruch naturalny i migracje w latach 1946-2015, w: Główny Urząd Statystyczny, [online], [dostęp: 03.04.2017]: <http://stat.gov.pl/obszary-tematyczne/ludnosc/ludnosc/ struktura-ludnosci, 16,1.html>.

${ }^{11}$ Por. tabela nr 4.

${ }^{12}$ Por. np. Ludność, ruch naturalny..., dz. cyt.

${ }^{13}$ Zestawienie na podstawie danych GUS. Por. Urodzenia w latach 1970-2015, w: Główny Urząd Statystyczny, [online], [dostęp: 03.04.2017]: <http://stat.gov.pl/obszary-tematyczne/ludnosc/ ludnosc/struktura-ludnosci,16,1.html>; Dzietność kobiet w latach 1960-2015, w: Główny Urząd Statystyczny, [online], [dostęp: 03.04.2017]: <http://stat.gov.pl/obszary-tematyczne/ludnosc/ludnosc/ struktura-ludnosci,16,1.html>; Ludność i ruch naturalny w 2016r., w: Główny Urząd Statystyczny, [online], [dostęp: 03.04.2017]: <http://stat.gov.pl/obszary-tematyczne/ludnosc/ludnosc/ludnosc-i-ruchnaturalny-w-2016-r-,30,1.html>. 
(TFR), określający liczbę urodzonych dzieci, jakie przypadają na jedną kobietę w wieku rozrodczym (15-49 lat). By można było mówić o zastępowalności pokoleń, TFR musi wynosić ok. 2,10-2,15 ${ }^{14}$. W Polsce wartość przekraczającą 2,10 po raz ostatni odnotowano w roku $1988(2,126)$, od początku lat 90. TFR wynosił poniżej 2, systematycznie spadając do roku $2003(1,222)$, by potem nieco wzrosnąć (w roku 2009 osiągnął najwyższy poziom w XXI wieku $-1,398)^{15}$.

O tym, jak niekorzystna jest sytuacja Polski, może świadczyć porównanie wskaźników TFR Polski i innych państw w latach 1990-2014. Analizując wskaźnik TFR dla państw należących do Unii Europejskiej (28 państw, łącznie z Wielką Brytanią), można zauważyć, że na przestrzeni niemal ćwierćwiecza (1990-2014) zasadniczo dominowała tendencja spadkowa - na 28 państw 19 miało wskaźnik TFR niższy w roku 2014 niż w roku 1990, cztery państwa utrzymały wskaźnik TFR na zbliżonym poziomie (Finlandia, Wielka Brytania, Dania, Luksemburg), wreszcie pięć państw odnotowało ostateczny wzrost wskaźnika TFR (Francja, Belgia, Holandia, Włochy, Słowenia) ${ }^{16}$.

Poziom zmian wskaźnika TFR w poszczególnych państwach był zróżnicowany, jednakże Polska może być zaliczona do tych państw, w których dokonała się największa zmiana na niekorzyść - w analizowanym okresie wskaźnik TFR zmniejszył się dla Polski o 0,8 (z 2,1 do 1,3); taką samą zmianę wskaźnika TFR odnotowano dla Słowacji i jedynie na Cyprze była ona większa (zmiana o 1,0 - spadek z 2,4 na 1,4). O zmianie poziomu wskaźnika TFR świadczy również miejsce na liście rankingowej dla roku 1990 i 2014: o ile w roku 1990 Polska razem z Irlandią, Słowacją i Estonią znajdowały się ex aequo na drugim miejscu na 28 obecnych państw członkowskich Unii Europejskiej (wyprzedzane jedynie przez Cypr), to w roku 2014 było to już drugie miejsce, ale od końca (ex aequo z Grecją, Słowacją i Hiszpanią; wskaźnik TFR na poziomie 1,3; gorszy miała jedynie Portugalia $-1,2)^{17}$.

Oceniając sytuację Polski pod kątem poziomu wskaźnika TFR szerzej niż tylko na tle Unii Europejskiej, można zauważyć, że wcale nie przedstawia się ona lepiej. W roku 1990 wyższy od Polski wskaźnik TFR miało 149 państw/ /terytoriów (na 218 uwzględnianych w zestawieniu Banku Światowego ${ }^{18}$; taki sam poziom wskaźnika TFR jak Polska miały wówczas: np. Estonia, Irlandia, Słowacja, Szwecja, USA); w roku 2000 były to już 173 państwa/terytoria

${ }^{14}$ Por. np. Ludność i ruch..., dz. cyt.

${ }^{15}$ Por. Dzietność..., dz. cyt. Dla porównania - w roku 1960 TFR wynosił 2,980...

${ }^{16}$ Obliczenia własne na podstawie: Fertility rate, total (births per woman), w: The World Bank, DataBank, World Development Indicators, [online], [dostęp: 03.04.2017]: <http://databank. worldbank.org $/$ data/reports.aspx? source $=2 \&$ series $=$ SP.DYN.TFRT.IN\&country=\#> .

${ }^{17}$ Obliczenia własne na podstawie: Fertility rate..., dz. cyt.

${ }^{18}$ Obliczenia własne na podstawie: Fertility rate..., dz. cyt. 
(poziom wskaźnika TFR taki jak Polska - 1,4 - miały wówczas np. Austria, Chiny, Estonia, Niemcy, Japonia, Litwa); wreszcie w roku 2014 TFR wyższy niż Polska miało 190 państw/terytoriów (taki sam jak Polska - 1,3 - miały np. Grecja, Singapur, Słowacja i Hiszpania $)^{19}$.

Z kolei dane publikowane przez Centralną Agencję Wywiadowczą (CIA) dla roku 2016 sytuują Polskę na pozycji 215 na 224 możliwe państwa/terytoria (TFR na poziomie 1,34; taki sam poziom TFR miała Rumunia, niższy np. Bośnia i Hercegowina, Korea (Południowa), Hong Kong, Taiwan, Makau, Singapur) ${ }^{20}$.

Przytoczone powyżej statystyki są na tyle wymowne, że komentarz wydaje się tu zbędny, niemniej można stwierdzić, parafrazując określenia z zakresu hydrologii, że nie ma tu mowy o ,stanach ostrzegawczych”, ale o dawno przekroczonych „stanach alarmowych”.

\section{Polityka rodzinna w Polsce}

W kontekście przywołanych powyżej danych oraz rozważań Jana Pawła II odnośnie do znaczenia polityki rodzinnej, trzeba zasygnalizować jej istotę i zadania. Za Bożeną Kłos i Jolantą Szymańczyk warto przywołać rozumienie polityki rodzinnej, sformułowane przez S.B. Kamerman, według której ,polityka rodzinna to całokształt norm prawnych, działań i środków uruchamianych przez państwo w celu stworzenia odpowiednich warunków życia dla rodziny; jej powstania, prawidłowego funkcjonowania i spełniania przez nią wszystkich ważnych społecznie ról"21. Tak rozumiana polityka rodzinna niewątpliwie wpisuje się w zakres działań podejmowanych w kontekście sytuacji demograficznej poszczególnych społeczeństw - np. wśród celów polityki ludnościowej, sfor-

${ }^{19}$ Warto w tym miejscu zaznaczyć, że jeszcze w połowie I dekady XXI wieku jeden z bardziej znanych demografów, Jerzy Holzer, odwołując się analiz GUS z przełomu stuleci, wskazywał, iż po spadku TFR, nastąpi jego wzrost, który w roku 2015 doprowadzi do osiągnięcia poziomu 1,59 i utrzymanie go do roku 2020. Por. J.Z. Holzer, Demograficzne uwarunkowania polityki społecznej, w: Polityka społeczna, red. A. Kurzynowski, Warszawa 2006, s. 21-36. Nowsze prognozy również mówią o wzroście TFR, choć nieco wolniejszym - w najbardziej optymistycznym wariancie poziom 1,6 ma zostać osiągnięty w roku 2025, natomiast w roku 2070 - w zależności od wariantu ma on wynosić od 1,399 (wariant niski) do 1,955 (wariant b. wysoki). Por. Prognoza ludności na lata 2014-2050 [online], Warszawa, Główny Urząd Statystyczny, 2014, [dostęp: 15.04.2017]: <http:// stat.gov.pl/obszary-tematyczne/ludnosc/prognoza-ludnosci/prognoza-ludnosci-na-lata-2014-2050opracowana-2014-r-, 1,5.html>, s. 56.

${ }^{20}$ Por. Country Comparison - Total Fertility Rate; w: Central Intelligence Agency, The World Factbook, [online], [dostęp: 03.04.2017]: <https://www.cia.gov/library/publications/the-worldfactbook/rankorder/2127rank.html>.

${ }^{21}$ B. Kłos, J. Szymańczyk, Polityka rodzinna: wybrane zagadnienia, [online], [dostęp: 05.04. 2017]: <http://biurose.sejm.gov.pl/teksty/i-584.htm>. 
mułowanych przez Rządową Radę Ludnościową w roku 2013, jako pierwszy wymienia się „tworzenie warunków sprzyjających powstawaniu rodzin, przede wszystkim poprzez zawieranie małżeństw i realizację planów prokreacyjnych"22. Z kolei Marek Okólski i Agnieszka Fihel, analizując politykę ludnościową, łączą ją z takimi aspektami polityki społecznej, jak polityka wzrostu demograficznego, polityka zdrowotna, polityka migracyjna i właśnie polityka rodzinna ${ }^{23}$.

Polityka rodzina - jak zresztą każdy obszar polityki społecznej - jest sferą ciągłych przemian i zderzania się różnych wizji i interesów. W Polsce po roku 1989 ścierały się przynajmniej trzy wizje polityki rodzinnej - liberalna, socjaldemokratyczna i konserwatywna, czego skutkiem - przy dość często zmieniających się w pierwszym dwudziestoleciu III Rzeczypospolitej układach parlamentarno-rządowych - był brak spójnej i stabilnej polityki rodzinnej ${ }^{24}$. Polityka rodzinna lat 90 . charakteryzowała się zmiennymi priorytetami rządowych programów (a zatem również zmiennością rodzaju i zakresu świadczeń), selektywnością świadczeń i koncentracją na ochronie rodzin najuboższych ${ }^{25}$. Sytuacja taka siłą rzeczy nie mogła mieć pozytywnie wpłynąć na decyzje prokreacyjne polskiego społeczeństwa. Jak zauważa Joanna Szczepaniak-Sienniak, pozytywna zmiana w zakresie polityki rodzinnej nastąpiła w Polsce dopiero po roku 2008, wraz ze wzrostem zainteresowania władz problemami rodziny i wprowadzeniem nowych rozwiązań z zakresu dotyczącej jej polityki ${ }^{26}$.

W Polsce jest ona realizowana przy użyciu różnorodnych narzędzi, które nie zawsze były/są ogólnodostępne, w niektórych bowiem przypadkach dostępność jest ograniczana np. przez kryterium dochodowe czy przynależność do grupy odbiorców o szczególnych potrzebach (np. niepełnosprawność). Można wymienić przynajmniej cztery grupy narzędzi: pieniężne świadczenia społeczne, instrumenty umożliwiające godzenie obowiązków zawodowych i rodzinnych, ulgi podatkowe oraz usługi społeczne ${ }^{27}$.

Pieniężne świadczenia społeczne są (czy raczej były do momentu wprowadzenia programu „500+”) narzędziem na ogół skierowanym do ograniczonej

${ }^{22}$ Rządowa Rada Ludnościowa, Założenia polityki ludnościowej Polski 2013. Projekt, Warszawa 2013, s. 13, [online], [dostęp: 05.04.2017]: <http://bip.stat.gov.pl/organizacja-statystykipublicznej/rzadowa-rada-ludnosciowa/dokumenty-rzadowej-rady-ludnosciowej/>. Pozostałe 3 cele są związane z kwestią starzenia się społeczeństwa, stanem jego zdrowia oraz migracjami.

${ }^{23}$ Por. M. Okólski, A. Fihel, Demografia. Wspótczesne zjawiska i teorie, Warszawa 2012.

${ }^{24}$ Por. G. Firlit-Fesnak, Rodziny polskie i polityka rodzinna; stan i kierunki przemian, w: G. Firlit-Fesnak M. Szylko-Skoczny, Polityka społeczna, Warszawa 2007, s. 187-199.

${ }^{25}$ Por. tamże.

${ }^{26}$ Por. J. Szczepaniak-Sienniak, Polityka rodzinna państwa we wspótczesnej Polsce, „Społeczeństwo i ekonomia" 2015, nr 2(4), [online], [dostęp: 08.04.2017]: <http://www.dbc.wroc.pl/ Content/31821/Szczepaniak-Sienniak_Polityka_Rodzinna_Panstwa_We_Wspolczenej_Polsce_ 2015.pdf $>$.

${ }^{27}$ Por. G. Firlit-Fesnak, Rodziny..., dz. cyt. 
grupy odbiorców - a więc do rodzin znajdujących się w trudnej sytuacji materialnej, a także doświadczających problemów związanych z realizacją funkcji opiekuńczej, wychowawczej czy edukacyjnej (np. niepełnosprawność dzieci, samotne wychowywanie dziecka etc. ${ }^{28}$. W tej grupie instrumentów wskazać można np. zasiłek rodzinny wraz z dodatkami (przyznawany po spełnieniu ustawowego kryterium dochodowego), świadczenia opiekuńcze związane z opieką nad dzieckiem niepełnosprawnym (np. zasiłek pielęgnacyjny czy świadczenie pielęgnacyjne $)^{29}$. Można tu również zaliczyć jednorazową zapomogę z tytułu urodzenia dziecka (potocznie zwaną „,becikowym”), wprowadzoną pierwotnie (w roku 2006) jako dostępną dla każdego rodzica. W późniejszym okresie jej dostępność została dwukrotnie ograniczona: w roku 2009 wprowadzono warunek pozostawania matki pod opieką medyczną w trakcie trwania ciąży, a w roku 2013 - wprowadzone zostało również kryterium dochodowe $^{30}$.

Polski system podatkowy w małym stopniu uwzględnia sytuację rodzinną podatnika (inna sytuacja istnieje chociażby we Francji, gdzie liczba dzieci w rodzinie ma znaczący wpływ na sposób rozliczania podatku ${ }^{31}$ ), niemniej funkcjonują $\mathrm{w}$ nim pewne elementy polityki rodzinnej w postaci różnego rodzaju ulg. W latach 1993-2001 funkcjonowała np. ulga związana $\mathrm{z}$ odpłatnym kształceniem dzieci w szkołach podstawowych, zawodowych i średnich, a w latach 1997-2004 - z odpłatnym kształceniem dzieci w szkołach wyższych $^{32}$. W roku 2007 została wprowadzona ulga $\mathrm{z}$ tytułu wychowywania dzieci, która początkowo nie była uzależniona od dochodu (takie ograniczenie pojawiło się w roku 2013 dla rodzin z jednym dzieckiem), ani zróżnicowana ze względu na liczbę dzieci (od 2013 roku rodzice wychowujący co najmniej troje dzieci korzystają z większych odliczeń) ${ }^{33}$. Za mające charakter prorodzinny można również uznać możliwość wspólnego opodatkowania małżonków, a także wspólnego z dziećmi rozliczania podatków przez osoby samotnie wychowujące dzieci ${ }^{34}$.

Kolejna grupa narzędzi to instrumenty umożliwiające godzenie obowiązków zawodowych i rodzinnych, do których można zaliczyć: urlopy i zasiłki

${ }^{28}$ Por. tamże; J. Szczepaniak-Sienniak, Polityka..., dz. cyt.

${ }^{29}$ Por. G. Firlit-Fesnak, Rodziny..., dz. cyt.; J. Szczepaniak-Sienniak, Polityka..., dz. cyt.

${ }^{30}$ Por. J. Szczepaniak-Sienniak, Polityka..., dz. cyt.

${ }^{31}$ Por. Kancelaria Senatu. Biuro Analiz i Dokumentacji, Wybrane zagadnienia polityki prorodzinnej w niektórych państwach Unii Europejskiej. Opracowania tematyczne. OT-617, Warszawa, Kancelaria Senatu, 2013, [online], [dostęp: 27.04.2017]: <http://www.senat.gov.pl/gfx/senat/pl/se natopracowania/48/plik/ot-617_do_internetu.pdf>.

${ }^{32}$ Por. np. Historia PIT od 1991 do 2015, w: Rozliczeniepit.pl, [online], 07.02.2015, [dostęp: 08.04.2017]: <http://rozliczeniepit.pl/ulgi-i-odliczenia/historia-pit-od-1991-2015/>.

${ }^{33}$ Por. J. Szczepaniak-Sienniak, Polityka..., dz. cyt.; Historia PIT..., dz. cyt.

${ }^{34}$ Por. G. Firlit-Fesnak, Rodziny..., dz. cyt. 
macierzyńskie/rodzicielskie (z których może skorzystać zarówno matka, jak i ojciec), urlopy i zasiłki wychowawcze, zasiłek opiekuńczy czy urlopy ojcowskie ${ }^{35}$.

Czwarta grupa narzędzi - usługi społeczne - związana jest z kwestiami edukacji, opieki nad dziećmi, wychowania, a także opieki zdrowotnej. Można tu wymienić np. funkcjonowanie takich instytucji, jak żłobki, kluby malucha, opiekunowie dzienni oraz różne formy wychowania przedszkolnego ${ }^{36}$.

Do przywołanych wyżej czterech grup można dodać jeszcze wprowadzoną w 2015 roku ogólnopolską Kartę Dużej Rodziny ${ }^{37}$ dla rodzin z trojgiem i więcej dzieci, bez względu na sytuację materialną. Niezależnie od niej funkcjonują również lokalne programy dla rodzin dużych - np. „Poznań PRO Rodzina - Karta Dużej Rodziny" ${ }^{38}$. Karty tego typu pozwalają na uzyskanie zniżek na zakup towarów i usług ${ }^{39}$.

Wśród narzędzi wyszczególnionych w pierwszej grupie (świadczeń pieniężnych) znajduje się jeszcze jedno - wprowadzone Ustawa o pomocy państwa $w$ wychowaniu dzieci $\mathrm{z}$ dnia 11 lutego 2016 roku $^{40}$ świadczenie wychowawcze, którego celem jest „częściowe pokrycie wydatków związanych $\mathrm{z}$ wychowaniem dziecka, w tym z opieką nad nim i zaspokojeniem jego potrzeb życiowych"41, zwane potocznie ,500+”. Świadczenie to jest przyznawane rodzicom lub opiekunom prawnym bądź faktycznym dziecka do momentu ukończenia przez nie 18 roku życia ${ }^{42}$, przy czym na pierwsze (lub jedyne) dziecko w rodzinie przysługuje ono w sytuacji, gdy dochód w przeliczeniu na członka rodziny nie przekracza kwoty 800 PLN lub 1200 PLN, jeśli członkiem rodziny jest dziecko niepełnosprawne ${ }^{43}$.

Wspomniane uregulowanie było $\mathrm{w}$ momencie wprowadzania świadczenia wychowawczego (i nadal jest) powodem jego krytyki. W mediach, mediach społecznościowych, na forach internetowych etc. można było spotkać się z zarzutami, że jest to uregulowanie niesprawiedliwe, dyskryminujące, wykluczające. Zarzuty te, które na pierwszy rzut oka mogą nawet wydawać się do

${ }^{35}$ Por. G. Firlit-Fesnak, Rodziny..., dz. cyt.; J. Szczepaniak-Sienniak, Polityka..., dz. cyt.

${ }^{36}$ Por. G. Firlit-Fesnak, Rodziny..., dz. cyt.; J. Szczepaniak-Sienniak, Polityka..., dz. cyt.

${ }^{37}$ Por. Czym jest Karta Dużej Rodziny?, w: Rodzina.gov.pl, [online], aktualizowany 06.12.2016, [dostęp: 27.04.2017]: <https://rodzina.gov.pl/duza-rodzina/karta-duzej-rodziny>.

${ }^{38}$ Por. Karta Rodziny Dużej, w: Poznan.pl, [online], [dostęp: 27.04.2017]: <http://www.poznan. $\mathrm{pl} / \mathrm{mim} / \mathrm{main} /$ karta-rodziny-duzej,p,24588,24590.html>.

${ }^{39}$ Por. G. Firlit-Fesnak, Rodziny..., dz. cyt.; J. Szczepaniak-Sienniak, Polityka ..., dz. cyt.

${ }^{40}$ Por. Ustawa o pomocy państwa w wychowaniu dzieci z dnia 11 lutego 2016 roku DzU z 2016 r. $\mathrm{Nr} 32$ poz. 195.

${ }^{41}$ Ustawa o pomocy państwa w wychowaniu dzieci z dnia 11 lutego 2016 roku DzU z 2016 r. Nr 32 poz. 195, art. 4, par. 1.

${ }^{42}$ Tamże, art. 4, par. 2 i 3.

${ }^{43}$ Tamże, art. 5, par. 3 i 4. 
pewnego stopnia zrozumiałe ${ }^{44}$, w kontekście celów, jakie stawiali sobie twórcy tego narzędzia, są nieuzasadnione. W wystąpieniu Elżbiety Rafalskiej (minister rodziny, pracy i polityki społecznej) podczas pierwszego czytania projektu ustawy wyraźnie zostało podkreślone, że „przyświecają mu trzy główne, równorzędne cele: zwiększenie wskaźnika dzietności, inwestycja w kapitał ludzki, redukcja biedy wśród najmłodszych Polaków"45. O ile w przypadku celów drugiego i trzeciego, mających charakter bardziej społeczno-ekonomiczny, można się jeszcze ze wspomnianymi zarzutami zgodzić, o tyle w kontekście celu pierwszego - wyraźnie demograficznego - nie ulega wątpliwości, że konieczna jest taka konstrukcja świadczenia wychowawczego, która nie tyle dyskryminuje rodziny z jednym dzieckiem, ile promuje te, które mają ich przynajmniej dwoje.

\section{Efekty polityki rodzinnej}

Czy polityka rodzinna prowadzi do osiągnięcia założonych celów? Wydaje się, że odpowiedź na to pytanie może być twierdząca. Jeśli chodzi o skutki wprowadzenia świadczenia wychowawczego - jak dotąd najkrócej stosowanego z narzędzi polityki rodzinnej - to po roku od jego wprowadzenia można przyjrzeć się jedynie pierwszym efektom (ze względu na krótki czas jego funkcjonowania $)^{46}$. Niemniej, według danych prezentowanych przez Ministerstwo Rodziny, Pracy i Polityki Społecznej - świadczenie rodzinne przyczyniło się do poprawy sytuacji materialnej polskich rodzin, czego wyrazem z jednej strony jest spadek liczby osób korzystających ze świadczeń pomocy społecznej oraz z dożywiania, z drugiej zaś wzrost konsumpcji (dóbr takich jak odzież, obuwie, dóbr i usług związanych z edukacją - książek i pomocy naukowych, dodatkowych zajęć, wycieczek i wyjazdów szkolnych, czy wreszcie zwiększo-

${ }^{44} \mathrm{~W}$ tym miejscu autor pomija inne wątpliwości związane $\mathrm{z}$, ,500+”, jakie pojawiały się $\mathrm{w}$ dyskusjach społecznych i sporach politycznych - jak np. związane z szeroko rozumianymi kosztami świadczenia wychowawczego czy źródłami jego finansowania. Kwestie te są istotne, jednakże w ramach niniejszego artykułu przyjęta została raczej optyka „potrzeb społecznych” niż „możliwości ekonomicznych”.

${ }^{45}$ Wystapienie Elżbiety Rafalskiej, Minister Rodziny, Pracy i Polityki Społecznej podczas pierwszego czytania rzadowego projektu ustawy o pomocy państwa $w$ wychowywaniu dzieci, w: Ministerstwo Rodziny, Pracy i Polityki Społecznej, [online], [dostęp: 18.04.2017]: <http://www.mpips. gov.pl/wsparcie-dla-rodzin-z-dziecmi/rodzina-500-plus/dokumenty-i-opracowania/wystapienieelzbiety-rafalskiej-minister-rodziny-pracy-i-polityki-spolecznej-podczas-pierwszego-czytaniarzadowego-projektu-ustawy-o-pomocy-panstwa-w-wychowywaniu-dzieci-/>.

${ }^{46}$ Pewien problem, jeśli chodzi o jego ocenę, stanowią pojawiające się w przestrzeni publicznej (np. w mediach) głosy, reprezentujące obie strony sporu wokół programu „500+”, które dalekie są chociażby od próby obiektywnego spojrzenia na wady i zalety wprowadzonego rozwiązania oraz jego efektywność. 
na liczba wyjazdów wakacyjnych). Istotnym skutkiem w tej sferze jest wzrost poziomu oszczędności polskich rodzin (część z nich zwiększyła dotychczasowe oszczędności, część zaczęła oszczędzać po raz pierwszy ${ }^{47}$. Trzeba jednak pamiętać, że efekty w sferze materialnej wynikają ze splotu różnego rodzaju przyczyn, wśród których świadczenie wychowawcze jest wprawdzie ważnym, ale nie jedynym elementem (można przywołać tu chociażby ogólną sytuację na rynku pracy czy niską stopę bezrobocia ${ }^{48}$ ).

Nie mniej istotne wydają się skutki o charakterze demograficznym. Informacje dostępne na stronach internetowych GUS ${ }^{49}$ pokazują, że w roku 2016, w którym przez dziewięć miesięcy było już przyznawane świadczenie rodzinne, urodziło się 382,3 tys. dzieci, co wobec 369,3 tys. dzieci urodzonych w roku 2015 oznacza wzrost liczby urodzeń o około 13 tys. Niestety, nie zostały jeszcze ${ }^{50}$ udostępnione przez GUS dane dla poszczególnych miesięcy 2016 roku, które pozwalałyby na porównanie sytuacji w odpowiednich miesiącach lat 2015 i 2016. Można jednak w tym miejscu porównać liczbę urodzeń w jednym miesiącu (styczniu) w latach 2002-2017.

Tabela 2

Liczba dzieci urodzonych (w tys.) w styczniu w latach 2002-2017 51

\begin{tabular}{|c|c|c|c|c|c|c|c|}
\hline Rok & $\begin{array}{c}\text { Liczba } \\
\text { urodzeń }\end{array}$ & Rok & $\begin{array}{c}\text { Liczba } \\
\text { urodzeń }\end{array}$ & Rok & $\begin{array}{c}\text { Liczba } \\
\text { urodzeń }\end{array}$ & Rok & $\begin{array}{c}\text { Liczba } \\
\text { urodzeń }\end{array}$ \\
\hline 2017 & ok. 35,0 & 2013 & 32,2 & 2009 & 35,3 & 2005 & 30,8 \\
\hline 2016 & ok. 30,8 & 2012 & 33,7 & 2008 & 35,5 & 2004 & 31,1 \\
\hline 2015 & 32,2 & 2011 & 33,4 & 2007 & 33,4 & 2003 & 29,8 \\
\hline 2014 & 32,1 & 2010 & 36 & 2006 & 31,2 & 2002 & 30,9 \\
\hline
\end{tabular}

47 Rok na plus, w: Ministerstwo Rodziny, Pracy i Polityki Społecznej, Rodzina 500 plus, [online], 31.03.2017, [dostęp: 26.07.2017]: <http:/www.mpips.gov.pl/aktualnosci-wszystkie/rodzi na-500-plus/art,8744,rok-na-plus.html>.

48 Por. Stopa bezrobocia w latach 1990-2017, w: Główny Urząd Statystyczny, [online], aktualizacja 26.04.2017, [dostęp: 28.04.2017]: <http://stat.gov.pl/obszary-tematyczne/rynek-pracy/ bezrobocie-rejestrowane/stopa-bezrobocia-w-latach-1990-2017,4,1.html>

${ }^{49}$ Por. Ludność i ruch..., dz. cyt.

50 Stan na koniec kwietnia 2017 roku.

51 Opracowanie własne na podstawie: dla roku 2017 i 2016 - 500+ ma udziat we wzroście narodzin, w: Ministerstwo Rodziny, Pracy i Polityki Społecznej, Rodzina 500 plus, [online], 23.03.2017, [dostęp: 26.07.2017]: <http:/www.mpips.gov.pl/aktualnosci-wszystkie/rodzina-500plus/art,8720,500-ma-udzial-we-wzroscie-narodzin.html>; dla lat 2002-2015 - Wyniki badań bieżacych, w: Główny Urząd Statystyczny, Baza Demografia, [online], [dostęp: 22.04.2017]: $<$ http://demografia.stat.gov.pl/bazademografia/Tables.aspx>. W przypadku lat 2002-2015 dane dotyczą urodzeń żywych, w przypadku lat 2016 i 2017 brak informacji, czy przedstawione liczby dotyczą urodzeń żywych czy urodzeń ogółem, niemniej ze względu na niewielkie różnice w liczbie urodzeń żywych i ogółem, dla celów niniejszego porównania można przyjąć te dane za wystarczające. 
W styczniu roku 2017 urodziło się wyraźnie więcej dzieci niż w analogicznym okresie roku 2016 (wzrost o 4,2 tys. - 13,6\%) - liczba zbliżona do liczby urodzeń w latach 2008-2010, kiedy odnotowano wzrost liczby urodzeń ze względu na wejście w okres decyzji prokreacyjnych osób urodzonych w czasie wyżu demograficznego z przełomu lat 70. i 80.. Dodatkowo można zauważyć, że w przywołanym okresie nigdy nie było tak dużej różnicy między liczbą urodzeń, jeśli porównywać kolejne następujące po sobie lata (największy spadek: -2,6 tys. - lata 2010-2011, największy wzrost: +2,2 tys. - lata 2006-2007). Interesujące są w tym kontekście informacje, że w listopadzie i grudniu 2016 roku odnotowano wzrost liczby urodzeń w porównaniu $\mathrm{z}$ analogicznymi okresami roku 2015, odpowiednio o 5 tys. oraz 5,7 tys. ${ }^{52}$ - jest to o tyle istotne, że dzieci urodzone $\mathrm{w}$ tych miesiącach zostały poczęte w okresie, kiedy wprowadzono świadczenie rodzinne.

Jak to już zostało zasygnalizowane, pozytywne zmiany w polityce rodzinnej zaczęto wprowadzać już wcześniej (np. wydłużanie urlopów macierzyńskich). W związku z powyższym pojawia się pytanie, czy można zaobserwować przełożenie się wcześniejszych zmian na sytuację demograficzną ${ }^{53}$. Zdaniem autora, można tu udzielić odpowiedzi pozytywnej - warto w tym kontekście sięgnąć do prognoz liczby urodzeń na lata 2014-2050, przygotowanej w roku 2014 przez GUS i porównać ją z dostępnymi danymi dotyczącymi rzeczywistej liczby urodzeń (lata 2014-2016).

Tabela 3.

Liczba urodzeń prognozowana przez GUS (scenariusze: niski, średni, wysoki i bardzo wysoki) a rzeczywista liczba urodzeń w latach 2014-2016 $6^{54}$

\begin{tabular}{|c|c|c|c|c|c|}
\hline Rok & Niski & Średni & Wysoki & Bardzo wysoki & Rzeczywista liczba urodzeń \\
\hline 2014 & 355809 & 360447 & 368847 & 371435 & 375160 \\
\hline 2015 & 343312 & 353909 & 367758 & 374245 & 369308 \\
\hline 2016 & 334540 & 348807 & 365369 & 376585 & 382300 \\
\hline
\end{tabular}

52 T. Sąsiada, Liczba urodzeń w Polsce zaskoczyła Rafalska. A w tym roku ma być jeszcze lepiej, w: WP money, [online], 31.01.2017, [dostęp: 20.02.2017]: <http://www.money.pl/gospodarka/ wiadomosci/artykul/500-liczba-urodzen-elzbieta-rafalska,212,0,2250964.html>. Na podstawie danych GUS za rok 2015 można wyliczyć, że jest to odpowiednio ok. 32,7 tys. urodzeń w listopadzie i ok. 34,4 tys. urodzeń grudniu - por. Wyniki badań..., dz. cyt.

${ }^{53}$ Należy pamiętać, że nie można tu mówić o prostej zależności przyczynowo-skutkowej, gdyż trzeba brać pod uwagę splot różnych uwarunkowań, które mogą motywować bądź demotywować do podejmowania decyzji prokreacyjnych (sytuacja ekonomiczna, wyznawany system wartości, migracje - zwłaszcza po wstąpieniu Polski do UE w roku 2004 etc.).

${ }^{54}$ Opracowanie własne na podstawie: Prognoza ludności..., dz. cyt, s. 157; Ludność i ruch..., dz. cyt. 
Wprawdzie przedstawione dane odnoszą się tylko do trzech lat (z tego 2 lata sprzed wprowadzenia „,500+”), jednakże można zauważyć, że rzeczywista liczba urodzeń przekroczyła prognozy GUS - dla lat 2014 i 2016 rzeczywista liczba urodzeń jest wyższa niż zakładana przez scenariusz „bardzo wysoki”, a w roku 2015 mieści się między wartościami ze scenariusza „wysokiego" i „bardzo wysokiego”. Również wartość wskaźnika TFR w latach 2014 i 2015 wypada zasadniczo korzystniej w porównaniu z prognozami z roku 2014: w roku 2014 wyniosła 1,290 (prognoza - wariant b. wysoki: 1,270), a w roku $2015-1,289$ (prognoza: wariant wysoki - 1,275, wariant b. wysoki-1,297) ${ }^{55}$.

Warto zwrócić uwagę również na kwestię rodzenia kolejnych dzieci przez kobietę.

Tabela 4.

Urodzenia żywe według kolejności urodzenia dziecka u matki w odsetkach w latach 2002-2015 56

\begin{tabular}{|c|c|c|c|c|c|c|c|c|}
\hline Rok & Dziecko & Dziecko & Dziecko & Dziecko & Dziecko & Dziecko & Dziecko & Dziecko \\
8 & 2 & 3 & 4 & 5 & 6 & 7 & 8 i kolejne \\
\hline 2015 & 47,0 & 37,6 & 10,6 & 2,7 & 0,9 & 0,3 & 0,2 & 0,1 \\
\hline 2014 & 47,4 & 37,5 & 10,5 & 2,8 & 1,0 & 0,4 & 0,2 & 0,2 \\
\hline 2013 & 48,6 & 36,4 & 10,4 & 2,8 & 1,0 & 0,4 & 0,2 & 0,2 \\
\hline 2012 & 48,7 & 36,3 & 10,2 & 2,9 & 1,0 & 0,4 & 0,2 & 0,2 \\
\hline 2011 & 49,2 & 35,9 & 10,2 & 2,9 & 1,0 & 0,4 & 0,2 & 0,2 \\
\hline 2010 & 50,1 & 35,1 & 9,9 & 2,9 & 1,0 & 0,4 & 0,2 & 0,2 \\
\hline 2009 & 50,9 & 34,4 & 9,8 & 2,9 & 1,1 & 0,5 & 0,2 & 0,2 \\
\hline 2008 & 50,8 & 34,3 & 9,8 & 3,0 & 1,1 & 0,5 & 0,2 & 0,3 \\
\hline 2007 & 50,8 & 33,5 & 10,0 & 3,2 & 1,3 & 0,6 & 0,3 & 0,3 \\
\hline 2006 & 51,3 & 32,7 & 10,0 & 3,4 & 1,3 & 0,6 & 0,3 & 0,4 \\
\hline 2005 & 51,2 & 32,1 & 10,2 & 3,5 & 1,5 & 0,7 & 0,4 & 0,4 \\
\hline 2004 & 50,7 & 31,4 & 10,6 & 3,9 & 1,7 & 0,8 & 0,4 & 0,5 \\
\hline 2003 & 50,3 & 30,9 & 10,9 & 4,1 & 1,8 & 0,9 & 0,5 & 0,5 \\
\hline 2002 & 48,7 & 31,1 & 11,6 & 4,6 & 2,1 & 1,0 & 0,5 & 0,6 \\
\hline
\end{tabular}

$\mathrm{Z}$ przedstawionych $\mathrm{w}$ tabeli 4 danych najbardziej istotne wydają się te, które pokazują wzrost odsetka urodzeń drugich i trzecich dzieci matki. O ile w przypadku rodzenia się dzieci drugich wzrost odsetka może wynikać z decy-

\footnotetext{
${ }^{55}$ Por. Dzietność..., dz. cyt.; Prognoza ludności..., dz. cyt., s. 56.

${ }^{56}$ Obliczenia własne na podstawie danych GUS - por. Wyniki badań..., dz. cyt.
} 
zji podjętej przez osoby, które pierwsze dziecko urodziły w latach 2008-2010 i planowały kolejne dziecko niezależnie od sytuacji (choć decyzja oczywiście może być też skutkiem zmian w polityce rodzinnej - dziecko mogło wcześniej nie być planowane), o tyle w przypadku rodzenia dzieci trzecich najbardziej interesujące wydaje się najpierw zahamowanie, a potem odwrócenie tendencji spadkowej odsetka urodzenia trzeciego dziecka, co pokrywa się czasowo z początkiem zmian w polityce rodzinnej. Można zatem sądzić, że wprowadzone rozwiązania nie pozostawały bez wpływu na rozrodczość.

Odnosząc się do pytania postawionego na początku artykułu, można uznać, że przynajmniej od dekady, a w sposób szczególnie widoczny w chwili obecnej, polityka rodzinna pozwala rodzicom na większe otwarcie się na dzieci (w tym kolejne). Co więcej, minister rodziny, pracy i polityki społecznej zakłada, że w roku 2017 można spodziewać się kolejnego wzrostu liczby urodzeń - o 25-30 tys. w porównaniu z rokiem $2016^{57}$. Oznacza to, że w chwili obecnej - przynajmniej do pewnego stopnia - realizowane są postulaty dotyczące charakteru polityki rodzinnej, zawarte w Evangelium vitae. Potrzeba jednak czasu, aby można było dokonać szerszej analizy związków polityki rodzinnej z rozrodczością (zwłaszcza jeśli chodzi o „,500+”).

Wydaje się, że w dłuższej perspektywie czasowej zmiany wprowadzone w polityce rodzinnej mogą niestety nie wystarczyć jako zachęta do zwiększania dzietności. Obecny wzrost liczby urodzeń może wynikać np. z przyspieszenia decyzji prokreacyjnych ze względu na sprzyjającą sytuację ekonomiczną (decyzja o kolejnym dziecku - ale być może takim, które miało być drugim lub trzecim w rodzinie i zarazem ostatnim), we wcześniejszym okresie odkładanych na bliżej nieokreśloną przyszłość. W kolejnych latach problemem będzie jednak zmniejszanie się liczby kobiet w wieku rozrodczym, które będą zdolne rodzić dzieci (jako wynik niskiej dzietności we wcześniejszym okresie) ${ }^{58}$.

Biorąc pod uwagę zmniejszającą się liczbę matek w przyszłości oraz to, iż role społeczne kobiet uległy istotnym przekształceniom (chociażby ze względu na silne zaangażowanie w pracę zawodową, co siłą rzeczy musi przekładać się na decyzje prokreacyjne), nie ulega wątpliwości, iż konieczny jest dalszy

${ }^{57}$ Por. T. Sąsiada, Liczba..., dz. cyt.

${ }^{58}$ Por. np. Ekspert: w Polsce nie będzie baby boom, najwyżej zmniejszenie..., w: Rynekzdrowia. pl, [online], 17.02.2017, [dostęp: 28.04.2017]: <http://www.rynekzdrowia.pl/Polityka-zdrowotna/ Ekspert-w-Polsce-nie-bedzie-baby-boom-najwyzej-zmniejszenie, 159370,14.html>; Badanie SGH: nie ma szans na wzrost liczby urodzeń, w: Rynekzdrowia.pl, [online], 08.06.2013, [dostęp: 28.04.2017]: $<$ http://www.rynekzdrowia.pl/Polityka-zdrowotna/Badanie-SGH-nie-ma-szans-na-wzrost-liczbyurodzen, 131224,14.html>. 
rozwój instrumentów polityki rodzinnej. Szczególnie ważny - co podkreślają np. Anna Baranowska-Rataj i Anna Matysiak - wydaje się rozwój narzędzi opiekuńczych, które pozwalałyby łączyć role rodzicielskie z aktywnością zawodową (np. nowe rozwiązania dotyczące urlopów macierzyńskich i wychowawczych oraz związanych z nimi zasiłków, które premiowałyby skrócenie czasu między urodzeniem się kolejnych dzieci czy nowe rozwiązania z zakresu opieki instytucjonalnej nad małym dzieckiem) ${ }^{59}$. Pozostaje mieć nadzieję, że w najbliższej przyszłości będą podejmowane kolejne kroki w stronę postulowanego przez Jana Pawła II wspierania rodzin. Jeżeli nie doprowadzą one do dalszego podnoszenia liczby urodzeń, to być może przyczynią się chociaż do utrzymania tej liczby na poziomie zbliżonym do obecnego.

FAMILY POLICY IN POLAND AND EVANGELIUM VITAE

\section{Summary}

The encyclical Evangelium Vitae underlines the importance of family policy in the context of - among others - demographics. The demographic situation of Poland is particularly unfavourable (in the 21 st century TFR fluctuated between 1,2 and 1,4). After 1989 no coherent, well-planned family policy was developed in Poland, and it was only in the last decade when some positive changes started to occur. Changes in the legislation regarding maternity leaves and childcare and the introduction of the new "Family 500+" benefit in 2016 can be listed among promising solutions. One can already note the positive effects of some of these changes, such as the increased number of births.

Słowa kluczowe: polityka rodzinna; sytuacja demograficzna; płodność; świadczenie wychowawcze

Keywords: family policy; demographic situation; fertility; family benefit

\section{BIBLIOGRAFIA}

500+ ma udział we wzroście narodzin, w: Ministerstwo Rodziny, Pracy i Polityki Społecznej, Rodzina 500 plus, [online], 23.03.2017, [dostęp: 26.07.2017]: <http://www.mpips.gov.pl/aktualnosci-wszystkie/rodzina-500-plus/art,8720,500-ma-udzial-we-wzroscie-narodzin.html>.

59 Por. np. A. Baranowska-Rataj, A. Matysiak, Czy znamy lekarstwo na niska dzietność? Międzynarodowe badania ewaluacyjne na temat polityki rodzinnej, „Polityka społeczna”, 2012 nr 7, s. 9-14; Ekspert..., dz. cyt. 
Badanie SGH: nie ma szans na wzrost liczby urodzeń, w: Rynekzdrowia.pl, [online], 08.06.2013, [dostęp: 28.04.2017]: <http://www.rynekzdrowia.pl/Polityka-zdrowotna/Badanie-SGH-nie-maszans-na-wzrost-liczby-urodzen, 131224,14.html>.

Baranowska-Rataj A., Matysiak A., Czy znamy lekarstwo na niska dzietność? Międzynarodowe badania ewaluacyjne na temat polityki rodzinnej, „Polityka społeczna”, 2012 nr 7, s. 9-14.

Country Comparison - Total Fertility Rate; w: Central Intelligence Agency, The World Factbook, [online], [dostęp: 03.04.2017]: <https://www.cia.gov/library/publications/the-world-factbook/ rankorder/2127rank.html>.

Czym jest Karta Dużej Rodziny?, w: Rodzina.gov.pl, [online], aktualizowany 06.12.2016, [dostęp: 27.04.2017]: <https://rodzina.gov.pl/duza-rodzina/karta-duzej-rodziny>.

Dzietność kobiet w latach 1960-2015, w: Główny Urząd Statystyczny, [online], [dostęp: 03.04.2017]: $<$ http://stat.gov.pl/obszary-tematyczne/ludnosc/ludnosc/struktura-ludnosci,16,1.html>.

Ekspert: w Polsce nie będzie baby boom, najwyżej zmniejszenie..., w: Rynekzdrowia.pl, [online], 17.02.2017, [dostęp: 28.04.2017]: <http://www.rynekzdrowia.p1/Polityka-zdrowotna/Ekspertw-Polsce-nie-bedzie-baby-boom-najwyzej-zmniejszenie, 159370,14.html>.

Fertility rate, total (births per woman), w: The World Bank, DataBank, World Development Indicators, [online], [dostęp: 03.04.2017]: <http://databank.worldbank.org/data/reports.aspx?source$=2 \&$ series $=$ SP.DYN.TFRT.IN\&country $=\#>$.

Firlit-Fesnak G., Rodziny polskie i polityka rodzinna; stan i kierunki przemian, w: Firlit-Fesnak G., Szylko-Skoczny M., Polityka społeczna, Warszawa, Wydawnictwo Naukowe PWN, 2007, s. $187-199$.

Historia PIT od 1991 do 2015, w: Rozliczeniepit.pl, [online], 07.02.2015, [dostęp: 08.04.2017]: $<$ http://rozliczeniepit.pl/ulgi-i-odliczenia/historia-pit-od-1991-2015/>.

Holzer J. Z., Demograficzne uwarunkowania polityki spolecznej, w: Polityka społeczna, red. A. Kurzynowski, Warszawa, Szkoła Główna Handlowa, 2006, s. 21-36.

Jan Paweł II, Evangelium vitae, w: Posoborowe dokumenty Kościoła Katolickiego o matżeństwie i rodzinie, red. K. Lubowiecki, Kraków, Wydawnictwo „M”, 1999², t. II, s. 151-278.

Kancelaria Senatu. Biuro Analiz i Dokumentacji, Wybrane zagadnienia polityki prorodzinnej w niektórych państwach Unii Europejskiej. Opracowania tematyczne. OT-617, Warszawa, Kancelaria Senatu, 2013, [online], [dostęp: 27.04.2017]: <http://www.senat.gov.pl/gfx/senat/pl/senato pracowania/48/plik/ot-617_do_internetu.pdf>.

Karta Rodziny Dużej, w: Poznan.pl, [online], [dostęp: 27.04.2017]: <http://www.poznan.pl/mim/ main/karta-rodziny-duzej,p,24588,24590.html>.

Kłos B., Szymańczyk J., Polityka rodzinna: wybrane zagadnienia, [online], ], [dostęp: 05.04.2017]: http://biurose.sejm.gov.p1/teksty/i-584.htm>.

Ludność i ruch naturalny w 2016r., w: Główny Urząd Statystyczny, [online], [dostęp: 03.04.2017]: $<$ http://stat.gov.pl/obszary-tematyczne/ludnosc/ludnosc/ludnosc-i-ruch-naturalny-w-2016-r-,30,1.html>.

Ludność, ruch naturalny i migracje w latach 1946-2015, w: Główny Urząd Statystyczny, [online], [dostęp: 03.04.2017]: <http://stat.gov.pl/obszary-tematyczne/ludnosc/ludnosc/struktura-ludnosci, $16,1$. html $>$.

Okólski M., Fihel A., Demografia. Współczesne zjawiska i teorie, Warszawa, Wydawnictwo Naukowe SCHOLAR, 2012.

Prognoza ludności na lata 2014-2050, Warszawa, Główny Urząd Statystyczny, 2014, [online], [dostęp: 15.04.2017]: <http://stat.gov.pl/obszary-tematyczne/ludnosc/prognoza-ludnosci/progno za-ludnosci-na-lata-2014-2050-opracowana-2014-r-,1,5.html>.

Rok na plus, w: Ministerstwo Rodziny, Pracy i Polityki Społecznej, Rodzina 500 plus, [online], 31.03.2017, [dostęp: 26.07.2017]: <http://www.mpips.gov.pl/aktualnosci-wszystkie/rodzina-500-plus/art,8744,rok-na-plus.html>.

Rządowa Rada Ludnościowa, Założenia polityki ludnościowej Polski 2013. Projekt, Warszawa 2013, [online], [dostęp: 05.04.2017]: <http://bip.stat.gov.pl/organizacja-statystyki-publicznej/ rzadowa-rada-ludnosciowa/dokumenty-rzadowej-rady-ludnosciowej/>. 
Sąsiada T., Liczba urodzeń w Polsce zaskoczyla Rafalska. A w tym roku ma być jeszcze lepiej, w: WP money, [online], 31.01.2017, [dostęp: 20.02.2017]: <http://www.money.pl/gospodarka/wiado mosci/artykul/500-liczba-urodzen-elzbieta-rafalska,212,0,2250964.html> .

Stopa bezrobocia $w$ latach 1990-2017, w: Główny Urząd Statystyczny, [online], aktualizacja 26.04.2017, [dostęp: 28.04.2017]: <http://stat.gov.pl/obszary-tematyczne/rynek-pracy/bezrobo cie-rejestrowane/stopa-bezrobocia-w-latach-1990-2017,4,1.html>.

Szczepaniak-Sienniak J., Polityka rodzinna państwa we współczesnej Polsce, „Społeczeństwo i ekonomia" 2015, nr 2(4), [online], [dostęp: 08.04.2017]: <http://www.dbc.wroc.pl/Content/31821/ Szczepaniak-Sienniak_Polityka_Rodzinna_Panstwa_We_Wspolczenej_Polsce_2015.pdf > .

Urodzenia w latach 1970-2015, w: Główny Urząd Statystyczny, [online], [dostęp: 03.04.2017]: $<$ http://stat.gov.pl/obszary-tematyczne/ludnosc/ludnosc/struktura-ludnosci,16,1.html>.

Ustawa o pomocy państwa w wychowaniu dzieci z dnia 11 lutego 2016 roku DzU z 2016 r. Nr 32 poz. 195.

Wyniki badań bieżacych, w: Główny Urząd Statystyczny, Baza Demografia, [online], [dostęp: 22.04.2017]: <http://demografia.stat.gov.pl/bazademografia/Tables.aspx>.

Wystapienie Elżbiety Rafalskiej, Minister Rodziny, Pracy i Polityki Spolecznej podczas pierwszego czytania rzadowego projektu ustawy o pomocy państwa w wychowywaniu dzieci, w: Ministerstwo Rodziny, Pracy i Polityki Społecznej, [online], [dostęp: 18.04.2017]: <http://www.mpips. gov.pl/wsparcie-dla-rodzin-z-dziecmi/rodzina-500-plus/dokumenty-i-opracowania/wystapie nie-elzbiety-rafalskiej-minister-rodziny-pracy-i-polityki-spolecznej-podczas-pierwszegoczytania-rzadowego-projektu-ustawy-o-pomocy-panstwa-w-wychowywaniu-dzieci-/>.

MiKolaJ GĘBKA - dr nauk humanistycznych, socjolog, adiunkt na Wydziale Teologicznym UAM w Poznaniu, absolwent Podyplomowego Studium Rodziny na Wydziale Teologicznym UAM (2003). Autor ok. 20 artykułów. Zajmuje się problematyką rodzinną - praca magisterska (2001) poświęcona młodym małżeństwom, praca doktorska (2008) - społecznej roli ojca. Obecnie zajmuje się problemem dysfunkcji funkcji prokreacyjnej rodziny. 